\title{
Study on the Distribution of Sulfonamide Resistant Genes in Sludge Treatment Wetland
}

\author{
Yi-Man Niu a , Yu-bo Cui ${ }^{\text {b, * }}{ }^{\text {, Jun-Yu Liang }}{ }^{\mathrm{c}}$, Xin Li ${ }^{\mathrm{d}}$, Peng-Ju Zhang ${ }^{\mathrm{e}}$, and \\ Shu-Chang Zhang ${ }^{f}$ \\ College of Environment and Resources, Dalian Minzu University, Dalian 116600, China, \\ ${ }^{*}$ Corresponding author \\ a1217420377@qq.com, bcyb@dlnu.edu.cn, c1031223035@qq.com, d395525756@qq.com,

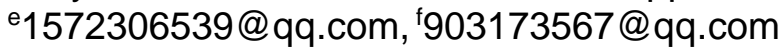

\begin{abstract}
Keywords: Sludge treatment wetland; Resistance genes; Sludge drying reed beds
Abstract. With the widespread use of antibiotics, environmental hazards caused by antibiotics and resistant bacteria residues have attracted wide public attention. In this paper, fluorescence quantitative PCR was used to detect and analyze the removal, distribution and influencing factors of four sulfonamide antibiotic resistant genes ( $s u l 1$, sul2, sul3,sulA) from sludge accumulated in Reed bed of sludge drying at loading stage. The results showed that there was significant difference in abundance of four sulfonamide resistant genes in the accumulated sludge, the average absolute contents were $1.61 * 10^{8}$ copies $/ g, 1.04 * 10^{8}$ copies $/ g, 4.31 * 10^{5}$ copies $/ g$, and $1.22 * 10^{6}$ copies/g respectively. The accumulation level of resistant genes in the bottom layer of sludge was lower than that in the surface layer, and the root environment of reed was favorable to the removal of resistance genes.
\end{abstract}

\section{Introduction}

Since antibiotics were discovered, they have been widely used due to their fast and efficient characteristics, and have made important contributions to human infectious diseases. In addition, due to its role in preventing diseases and stimulating growth, it has long been added to feed and is widely used in the aquaculture industry worldwide [1][2]. However, most of the antibiotics that are ingested into humans and animals cannot be absorbed and excreted into the environment as the feces are excreted.

The use of large amounts of antibiotics has led to an increase in antibiotic contamination in the environment. Associated with this is the development, spread and spread of resistant bacteria (Antibiotic Resistance Bacteria, ARB) and antibiotic resistance genes (ARGs) [3]. . Proliferation and spread of resistance genes in the environment will cause the body to develop drug resistance over time, creating potential risks to human health and the ecological environment [4]. For long-term use of antibiotics, resistant strains that induce the production of antibiotics in animals will be released into the environment with feces and the like. This pathway is considered to be the most important source of resistant bacteria in the environment [5], and resistance genes carried by resistant strains can be By horizontal transfer, the indigenous bacteria in the environment obtain resistance genes, thereby forming an environmental resistance gene bank [6]. The existence of ARGs is the root cause of bacterial resistance. Since Pruden et al. [7] proposed ARGs as a new type of environmental pollutants, reports of pollution and diffusion of ARGs in the environment have been increasing, in a variety of environmental media ( Various high abundance antibiotic resistance genes have been detected in sewage treatment plants, aquaculture waters, rivers, sediments, and soils. High-abundance antibiotic resistance genes exist in sewage treatment plants, especially sludge. If the sludge with residual antibiotic resistance genes is not properly handled, they will be one of the main reasons for non-point source pollution of antibiotic resistance genes.

The sludge drying of reed beds is a relatively new type of sludge stabilization technology that has been extensively studied and applied in recent years. The technology is periodically applied to the surface of artificial wetlands. Solid matter is trapped and gradually stabilized under natural forces such as plants, microorganisms, and sunlight [8][9]. However, the research on the removal effect of 
the resistance gene is still blank. In this study, starting from sulfonamide antibiotic resistance genes, through comparative experiments, the changes of sulfa antibiotic resistance genes in sludge stabilized by reed beds were investigated to explore the role of sludge drying in reed beds against antibiotics.

\section{Materials and Methods}

Experiment Run and Sampling. The dried sludge reed bed comparison experiment site is located in Dalian Sewage Treatment Co., Ltd. The effective area is $3.0 \mathrm{~m} \times 3.0 \mathrm{~m}$ and is divided into 1,2 , and 3 units (each occupying $3.0 \mathrm{~m} \times 1.0 \mathrm{~m}$ ). Among them, the 1 and 2 units set up ventilation pipes, and the 2 and 3 units planted reeds, and each unit operates independently. The height of the filling material in the bed is $65 \mathrm{~cm}$. From the bottom to the top, slag $20 \mathrm{~cm}$, gravel $20 \mathrm{~cm}$, and English sand filter material are $25 \mathrm{~cm}$, of which the surface is $3 \mathrm{~cm}$ and fine sand, and the super high part is $65 \mathrm{~cm}$. Its role is to provide enough space for sludge accumulation. Into the mud is completed by the mud pipe, the drain pipe is located at the bottom of each unit.

The experiment runs using intermittent flow into the mud, seven days as a cycle, and the first day of each cycle into the mud. The first three years were into the mud period, the fourth year was the natural stability period, and the fifth year continued into the mud. In this study, in April, May, September and October in the fifth year of the operation, the samples of the surface and bottom layers of three different units were taken for analysis and testing. The sampling depth of the surface sludge was 2 - 3 $\mathrm{cm}$ below the surface of the sludge. Sludge sampling depth is $2-3 \mathrm{~cm}$ above the bottom of sludge layer. A total of 24 samples of sludge samples were collected. About $20 \mathrm{~g}$ of each sample was collected. The samples were collected and placed in a cryogenic ice box. They were quickly returned to the laboratory and stored at $-80^{\circ} \mathrm{C}$. for subsequent DNA extraction experiments.

DNA Extraction. In this study, total DNA was extracted using the FastDNA ${ }^{\circledR}$ Spin Kit for Soil Kit. Each sample was weighed in $0.4 \mathrm{~g}$ and added to the Lysing Matrix E tube in the kit. The sample was extracted according to the attached instructions. DNA, extracted DNA was measured by spectrophotometer and its concentration, A260/A280 was between 1.8-2.0, indicating that the extracted DNA sample was of higher purity. The resulting DNA was stored at $-20^{\circ} \mathrm{C}$ for subsequent experiments.

Ordinary PCR Reaction Procedures. Four common sulfa-resistance genes (sul1, sul2, sul3, sulA) were tested in this experiment and the primer sequences are shown in Table 1. Qualitative PCR reaction system is 20ul, including 2×EsTaqMasterMix, 10ul; 0.5ul DNA template; upstream and downstream primers are $2 \mathrm{ul}(10 \mathrm{uM})$ and $7.5 \mathrm{uldd} \mathrm{H} 2 \mathrm{O}$. The PCR reaction procedure was: pre-denaturation at $94^{\circ} \mathrm{C}$ for $5 \mathrm{~min}$, denaturation at $95^{\circ} \mathrm{C}$ for $30 \mathrm{~s}$, annealing for $30 \mathrm{~s}$, extension at $72^{\circ} \mathrm{C}$ for $1 \mathrm{~min}$ for 30 cycles, and final extension at $72^{\circ} \mathrm{C}$ for $10 \mathrm{~min}$. PCR products were detected by $1 \%$ agarose gel electrophoresis and preliminary observations were made.

RT-PCR quantitative analysis of resistance genes. Before the reaction, the sample DNA concentration was diluted to ensure that the template DNA content was 20ng. The quantitative PCR reaction was performed on the ABI 7500 real-time fluorescence quantitative PCR instrument. The fluorescence quantitative reaction system was 20ul, including 10ul of SYBR Green Master Mix; each of the upstream and downstream primers. $0.4 \mathrm{ul}(10 \mathrm{uM})$, template DNA $2 \mathrm{ul}(10 \mathrm{ng} / \mathrm{ul})$, ddH2O7.2ul, quantitative PCR reaction program: predenaturation at $95^{\circ} \mathrm{C}$ for $5 \mathrm{~min}$; denaturation at $95^{\circ} \mathrm{C}$ for $10 \mathrm{~s}$, annealing for $30 \mathrm{~s}$, extension at $72^{\circ} \mathrm{C}$ for $30 \mathrm{~s}$, scanning simultaneously for fluorescence signals when extended, 40 cycles of amplification stage; the instrument automatically adds a dissolution curve program, using sterile ultrapure water instead of the sample as a negative control, in order to ensure the accuracy of the data, repeat three times for each sample. 
Table 1 Primer Sequence Listing

\begin{tabular}{|c|c|c|c|c|c|}
\hline $\begin{array}{l}\text { Target } \\
\text { gene }\end{array}$ & Primer & sequence $\left(5^{\prime}-3^{\prime}\right)$ & $\begin{array}{l}\text { Product } \\
\text { length (bp) }\end{array}$ & $\begin{array}{c}\text { PCR } \\
\text { annealing } \\
\text { temperature } \\
\left({ }^{\circ} \mathrm{C}\right)\end{array}$ & $\begin{array}{l}\text { Referenc } \\
\text { es }\end{array}$ \\
\hline \multirow[t]{4}{*}{ sull } & sull $F$ & CACCGGAAACATC & \multirow{4}{*}{158} & \multirow{4}{*}{55} & \multirow{4}{*}[11]{} \\
\hline & sull-F & GCTGCA & & & \\
\hline & soul- $R$ & AAGTTCCGCCGCA & & & \\
\hline & $\operatorname{sut} 1-\Lambda$ & AGGCT & & & \\
\hline \multirow[t]{4}{*}{ sul2 } & & CTCCGATGGAGGC & \multirow{4}{*}{190} & \multirow{4}{*}{60} & \multirow{4}{*}[11]{} \\
\hline & sulz-F & CGGTAT & & & \\
\hline & sul2- $R$ & GGGAATGCCATCT & & & \\
\hline & $\operatorname{sul} 2-\Lambda$ & GCCTTGA & & & \\
\hline \multirow[t]{4}{*}{ sul3 } & cul3 & GGTTGAAGATGGA & & \multirow{4}{*}{60} & \multirow{4}{*}{ [11] } \\
\hline & suts-F & GCAGATG & \multirow{3}{*}{111} & & \\
\hline & cull__R & GCCTTAATGACAG & & & \\
\hline & sus $-\kappa$ & GTTTGAGTC & & & \\
\hline \multirow[t]{3}{*}{ sulA } & $\operatorname{sel}_{A-F}$ & TCTTGAGCAAGCAC & \multirow{3}{*}{299} & \multirow{3}{*}{60} & \multirow{3}{*}[11]{} \\
\hline & & TCCAGCAG & & & \\
\hline & sulA-R & $\begin{array}{l}\text { TCCAGCCTTAGCAA } \\
\text { CCACATGG }\end{array}$ & & & \\
\hline
\end{tabular}

\section{Results and Analysis}

Concentration Levels of Sulfonamide Resistance Genes in Sludge Dried Reed Beds. In order to study the distribution abundance of antibiotic resistance genes in the sludge, the absolute copy number of the four resistance genes in three different units was experimentally studied, and the system was operated in April, May, September and October to decontaminate. Mud samples were drawn as shown in Fig.1-Fig.4. The results showed that four sulfonamide antibiotic resistance genes were detected in the sludge.

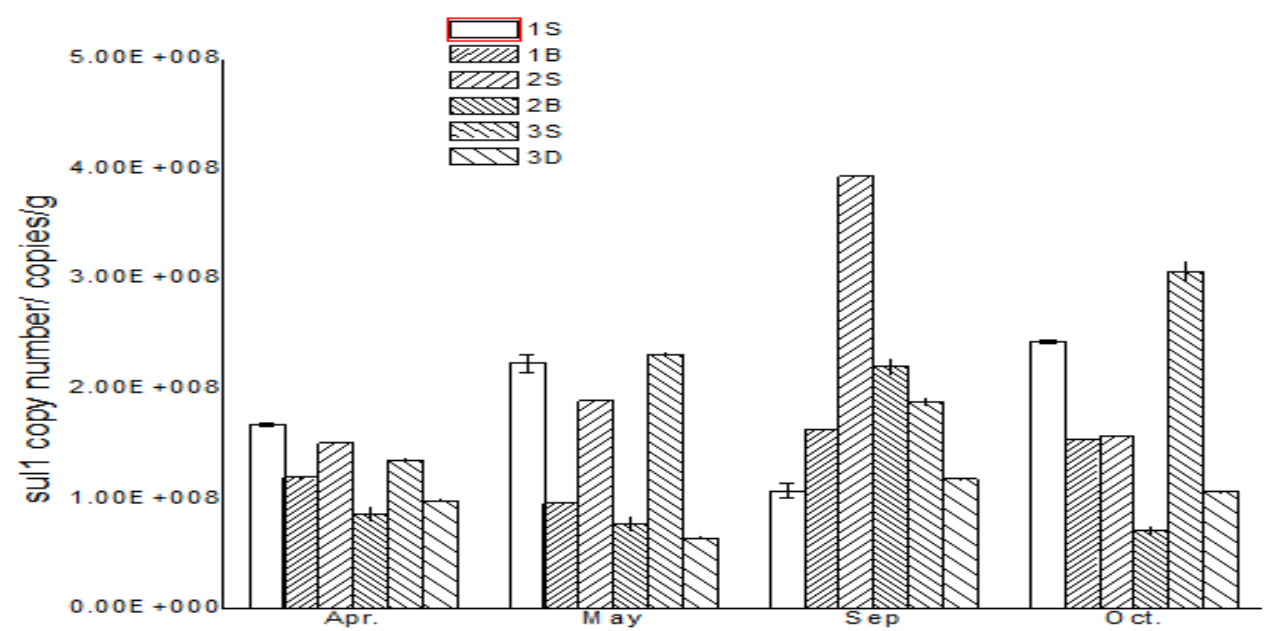

Fig. 1 Absolute copy number of sull resistance genes in sludge

The content of sull in the surface sludge of the three units was higher. In addition, the content of sull in the sludge contained in the unit 1, 3 was generally increased from April to October except for the decrease in September. In the 2-unit sludge, sull was in the range of 4-9. The monthly declining trend is increasing, and it is significantly lower again in October. sul2 is similar to the sul1 resistance gene. The average absolute copy number of sul3 in the three units of surface sludge was lower, with 
the highest performance in September in the 2 units and significantly lower in October. While the contents of units 1 and 3 were lower in September, the content of resistance genes increased significantly in October. In April, the three units of sulA resistance genes were all lower in May. The level of resistance genes in the unit sludge of September 2 was higher. In May, the absolute copy number of sulA was similar to the absolute copy number of sul3 in October. In the sludge, the abundances of the four sulfonamide-resistance genes are quite different. From the overall distribution, the relative abundances are as follows: sull> sul2> sul3> sulA. The reason for the high resistance gene abundance in the surface sludge of the September 2 unit was that the reed growth was lush and the lighting conditions were unfavorable, and the sulfa antibiotic resistance gene could not be effectively removed.

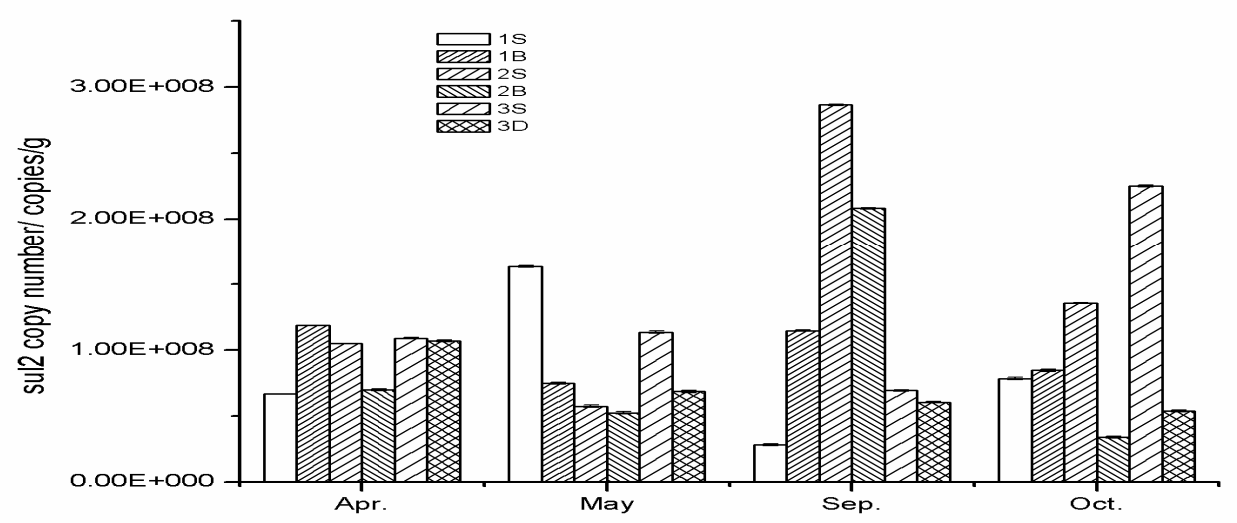

Fig. 2 Absolute copy number of sul2 resistance genes in sludge

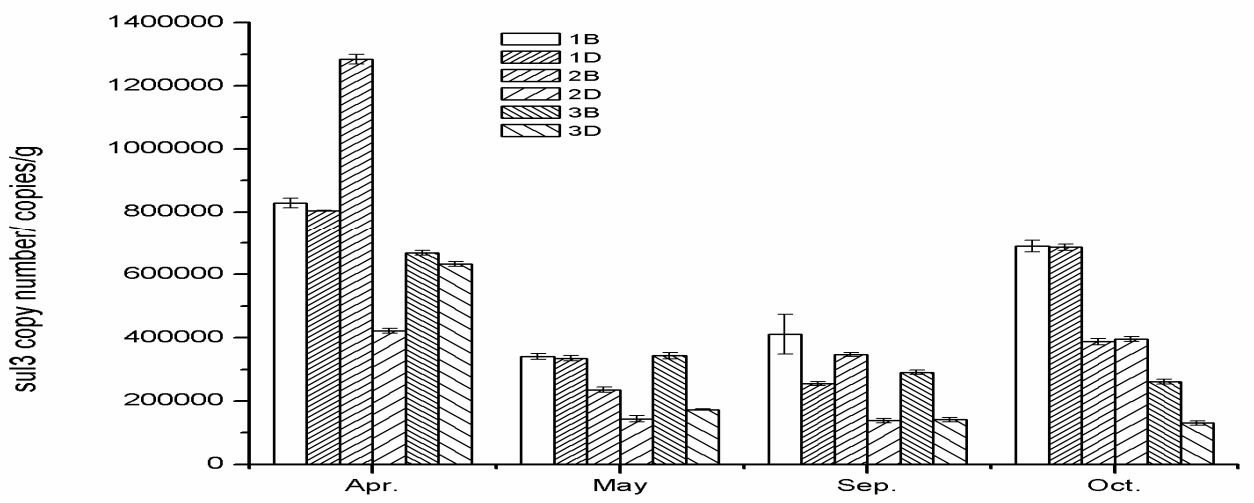

Fig. 3 Absolute copy number of sul3 resistance genes in sludge

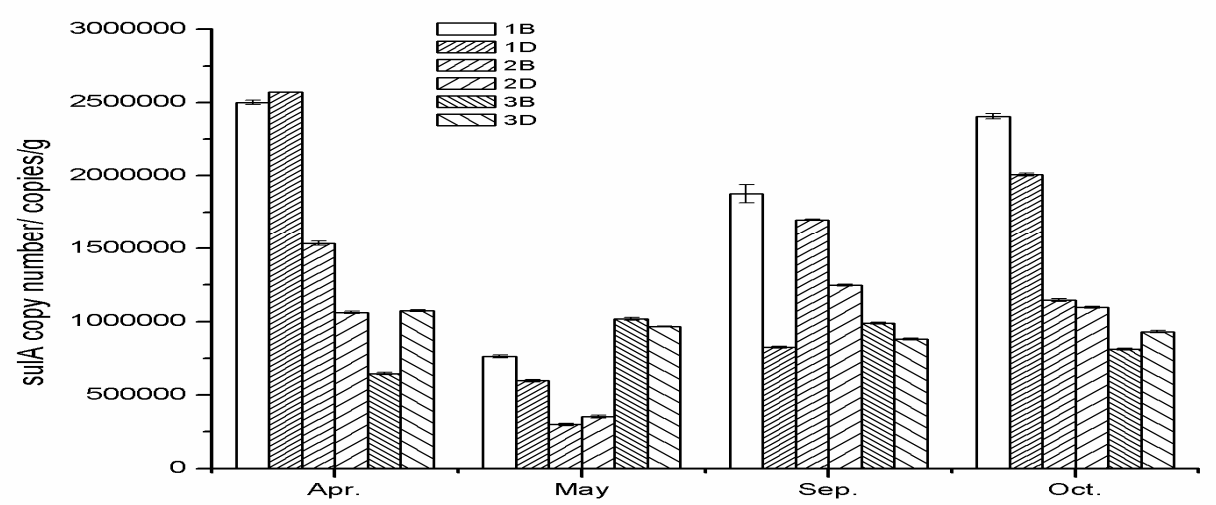

Fig. 4 Absolute copy number of sulA resistance genes in sludge 
Accumulation of Sulfonamide Antibiotic Resistance Genes in Sludge. This experiment studied the accumulation of sulfa antibiotic resistance genes in sludge dried reed beds and examined the differences between surface and bottom sludge samples.

The concentration of sull resistance genes in the bottom two units showed an upward trend from April to September, and showed a downward trend from September to October. Among them, the 3 -unit resistance gene reached its minimum value in June. The sul2 resistance gene concentration is similar to the sul1 resistance gene concentration. The sul3 resistance gene reached a minimum in May and September, and the sulA resistance gene reached a minimum in May. The surface resistance gene copy number is higher than the underlying resistance gene copy number. Studies have shown that high temperature, light, and anaerobic conditions can all promote the degradation of antibiotic resistance genes. The surface layer provides better light conditions, and the bottom layer can provide better anaerobic conditions. There are differences in different depths of sludge resistance genes, resulting in lower than the surface of the underlying layer is mainly due to the adsorption of resistant bacteria in the roots of reeds, which in turn leads to the degradation of resistance genes, this effect is more conducive to the removal of resistance genes.

\section{Conclusions}

In the sludge, the abundances of the four sulfonamide-resistance genes are quite different. From the overall distribution, the relative abundances are as follows: sull > sul2>sulA>sul3; accumulation of resistance genes in the bottom sludge. The level is lower than the surface sludge; the reed root environment is more conducive to the removal of resistance genes.

\section{Acknowledgements}

The research was financed by the National Natural Science Foundation of China and the Fundamental Research Funds for the Central Universities in China.

\section{References}

[1] S. Koike : Journal of environmental quality. Vol. 38 (2009), p. 1086-1108

[2] M. Hvistendahl : Science. Vol. 336(2012), p. 795-795

[3] X.Pan, Z.Ben, W.Ben: Chemosphere. Vol. 84(2011), p. 695-700

[4] M. Hvistendahl : Science. Vol. 336(2012), p. 795-795

[5] Y. Luo, Q.X. Zhou: Chinese Journal of Environmental Science. Vol. 28(2008), p.1499-1505

[6] B.J .Xu, Y.Luo, Q.X.Zhou: Environmental Chemistry. Vol. 29(2010), p.169-178

[7] A. Pruden, R. Pei, H. Storteboom: Environmental Science \& Technology. Vol. 40(2006), p. $7445-7450$

[8] Y.B.Cui, H.J.Sun, M.L.Yang: Journal of Residuals Science \& Technology. Vol. 9(2012), p. 47-53

[9] Y.B. Cui, X. H. Wu, Z. S Liu: Water Science and Technology. Vol. 58(2008), p. 1911-1916 